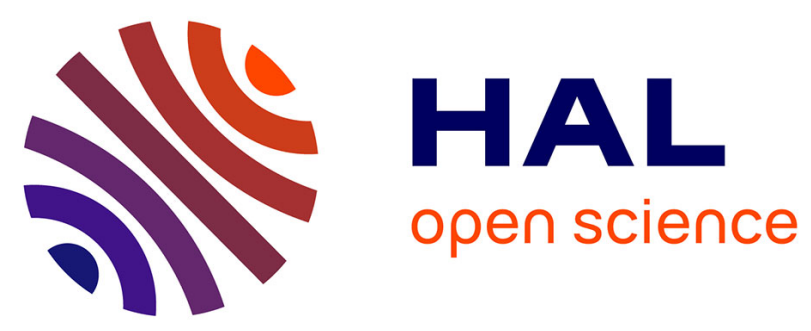

\title{
Influence of Mn addition on magnetic and structural properties of barium hexaferrite
}

A. Ghosh, Alexandre Pasko, S. N. Kane, M. Satalkar, R. Prasad, R. Diwedi, S. Ladole, A. S. Aswar, G. N. P. Oliveira, A. Apolinario, et al.

\section{- To cite this version:}

A. Ghosh, Alexandre Pasko, S. N. Kane, M. Satalkar, R. Prasad, et al.. Influence of Mn addition on magnetic and structural properties of barium hexaferrite. International Conference on Recent Trends in Applied Physics and Material Science (RAM 2013), Feb 2013, Bikaner, Rajasthan, India. pp.961-962, 10.1063/1.4810550 . hal-01734937

\section{HAL Id: hal-01734937 \\ https://hal.science/hal-01734937}

Submitted on 15 Mar 2018

HAL is a multi-disciplinary open access archive for the deposit and dissemination of scientific research documents, whether they are published or not. The documents may come from teaching and research institutions in France or abroad, or from public or private research centers.
L'archive ouverte pluridisciplinaire HAL, est destinée au dépôt et à la diffusion de documents scientifiques de niveau recherche, publiés ou non, émanant des établissements d'enseignement et de recherche français ou étrangers, des laboratoires publics ou privés. 


\title{
Influence of Mn Addition On Magnetic And Structural Properties of Barium Hexaferrite
}

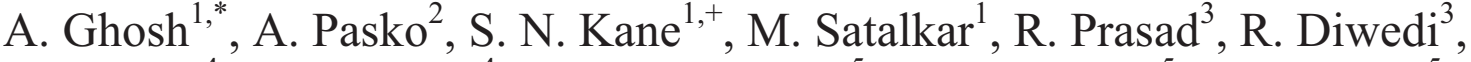 \\ S. Ladole ${ }^{4}$, A. S. Aswar ${ }^{4}$, G. N. P. Oliveira ${ }^{5}$, A. Apolinário ${ }^{5}$, C. T. Sousa ${ }^{5}$, \\ J. P. Araujo and F. Mazaleyrat ${ }^{2}$ \\ ${ }^{1}$ School of Physics, D. A. University, Khandwa Road, Indore - 452001, India \\ ${ }^{2}$ SATIE, UMR CNRS 8029, ENS de Cachan, 61, Avenue du Président Wilson, 94235 Cachan, France \\ ${ }^{3}$ School of Chemical Sciences, D. A. University, Khandwa Road, Indore - 452001, India \\ ${ }^{4}$ Department of Chemistry, S. G. B. Amravati University, Amravati-444602, India \\ ${ }^{5}$ IFIMUP/IN and Departamento de Fisica, Universidade de Porto, 4169-007 Porto, Portugal \\ *ghosh.arindam7@gmail.com,+kane_sn@yahoo.com
}

\begin{abstract}
Two-phase nano-powders based on Ba hexaferrite with addition of Mn have been obtained by a sol-gel autocombustion method. Composition dependence of magnetic and structural properties has been studied using magnetic measurements, X-ray diffraction (XRD) and scanning electron microscopy (SEM). The observed decrease of saturation magnetization and coercivity with increase of Mn content is mainly attributed to the presence of Fe oxide as a result of $\mathrm{Ba}$ depletion. SEM images show chemically homogeneous, non-regular shaped agglomerated nano-particles (50-200 $\mathrm{nm})$.
\end{abstract}

Keywords: Barium Ferrite, XRD, Magnetic measurements, SEM.

PACS: R61.05.cp, 75.47.Lx, 75.50.Gg

\section{INTRODUCTION AND EXPERIMENTS}

M-type hexaferrites have been the subject of intensive studies due to an appealing combination of good hard magnetic properties and low cost [1]. Attempts have been made to improve their magnetic properties by substituting $\mathrm{Fe}^{3+}$ with a different ion, e. g. $\mathrm{Mn}^{3+}[2]$. Another possible way is to make a spring magnet comprising two exchange-coupled (hard and soft) magnetic phases [3]. For the system involved, this can be a nano-composite of hexagonal ferrite $\mathrm{BaFe}_{12} \mathrm{O}_{19}$ and spinel ferrite $\mathrm{MnFe}_{2} \mathrm{O}_{4}$. In the present work we report on the effect of $\mathrm{Mn}$ addition combined with $\mathrm{Ba}$ depletion on magnetic and structural properties of $\mathrm{Ba}$ hexaferrite.

Powders with nominal composition $\mathrm{Ba}_{1-x} \mathrm{Mn}_{x}$ $\mathrm{Fe}_{12} \mathrm{O}_{19}(x=0,0.2,0.4,0.6,0.8)$ were prepared by a sol-gel auto-combustion technique [4], using carbonate and nitrates as sources of metals and citric acid as fuel. Final annealing, necessary for hexaferrite phase synthesis, was done at $800{ }^{\circ} \mathrm{C}$ for 4 hours (relatively low temperature to limit particle coarsening). Combustion method offers a quick hands-on route to produce fine hexaferrite precursors without any special setup or complex chemical reactions. X-ray diffraction measurements were done using a Bruker D8 Advance diffracttometer with $\mathrm{Cu}-\mathrm{K}_{\alpha}$ radiation. Low-vacuum field emission scanning electron microscopy (FE-SEM) imaging of the surfaces and energy dispersive X-ray spectroscopy (EDS) were performed with an FEI Quanta 400FEG. Room temperature magnetic hysteresis measurements were done by SQUID Magnetometer (Quantum Design MPMS-5S), with a maximum applied field of $\pm 5 \mathrm{~T}$, and were used to obtain coercivity $\left(\boldsymbol{H}_{c}\right)$ and saturation magnetization $\left(\boldsymbol{M}_{\boldsymbol{s}}\right)$.

\section{RESULTS AND DISCUSSIONS}

Figure 1 depicts the magnetization curves for $\mathrm{Ba}_{1-x} \mathrm{Mn}_{x} \mathrm{Fe}_{12} \mathrm{O}_{19}$ samples. Perusal of figure 1 reveals substantial decrease of saturation magnetization with increase of $x$ : obtained $\boldsymbol{M}_{\boldsymbol{s}}$ values for $x=0,0.2,0.4$, $0.6,0.8$ are respectively $60.12,61.85,49.76,30.08$,

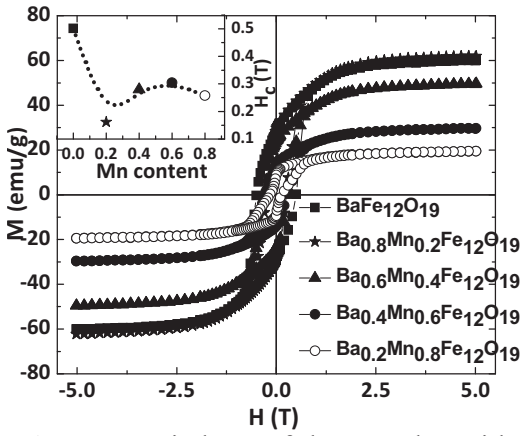

FIGURE 1. Hysteresis loop of the samples with different Mn concentration. Inset: $\boldsymbol{H}_{c}$ dependence. 
TABLE 1. Parameters of XRD analysis, obtained using Rietveld refinement, where $\boldsymbol{a}, \boldsymbol{c}$ - Lattice parameters, $\boldsymbol{D}$-Average grain diameter, wt. \% of the phase present in the sample.

\begin{tabular}{ccccccccc}
\hline \multicolumn{9}{c}{ M-ferrite } \\
\hline $\mathbf{M n}$ & $\boldsymbol{a}(\mathbf{n m})$ & $\boldsymbol{c}(\mathbf{n m})$ & $\boldsymbol{D}(\mathbf{n m})$ & wt. \% & $\boldsymbol{a}(\mathbf{n m})$ & $\boldsymbol{c}(\mathbf{n m})$ & $\boldsymbol{D}(\mathbf{n m})$ & wt. \% \\
\hline 0 & 0.5589 & 2.3215 & 78 & 98 & - & - & - & - \\
0.2 & 0.5892 & 2.3214 & 131 & 89 & 0.5042 & 1.3754 & 129 & 11 \\
0.4 & 0.5891 & 2.3202 & 124 & 73 & 0.5039 & 1.3744 & 131 & 27 \\
0.6 & 0.5891 & 2.3202 & 86 & 45 & 0.5038 & 1.3748 & 183 & 55 \\
0.8 & 0.5889 & 2.3190 & 51 & 28 & 0.5036 & 1.3744 & 218 & 72 \\
\hline
\end{tabular}

$19.32 \mathrm{emu} / \mathrm{g}$. Mn ions partially demolish the collinear ferrimagnetic structure of the hexaferrite, which results in the reduction of magnetization [2]. In our case, however, the drop of $\boldsymbol{M}_{\boldsymbol{s}}$ is mainly due to the presence of $\alpha-\mathrm{Fe}_{2} \mathrm{O}_{3}$ (hematite) phase confirmed by XRD. Inset of figure 1 shows the behavior of coercivity as a function of $x: \boldsymbol{H}_{c}$ becomes lower with introduction of $\mathrm{Mn}$. In a single-phase material, on the contrary, an increase of coercivity with increase of $\mathrm{Mn}$ concentration was observed [2].

Table 1 summarizes the lattice parameters $\boldsymbol{a}$ and $\boldsymbol{c}$, average grain size $\boldsymbol{D}$ and weight fraction of the phases present in the sample, obtained by XRD Rietveld refinement. Perusal of table 1 shows that the sample without $\mathrm{Mn}$ contains only pure $\mathrm{BaFe}_{12} \mathrm{O}_{19}$ phase, with $\boldsymbol{a}$ and $\boldsymbol{c}$ matching well the reported values [1]. With introduction of $\mathrm{Mn}$, new $\alpha-\mathrm{Fe}_{2} \mathrm{O}_{3}$ phase appears while the fraction of $\mathrm{BaFe}_{12} \mathrm{O}_{19}$ phase gradually decreases. Since no $\mathrm{MnFe}_{2} \mathrm{O}_{4}$ phase is detected, $\mathrm{Mn}$ partially substitutes $\mathrm{Fe}$ in $\mathrm{Ba}$ hexaferrite and/or $\mathrm{Fe}$ oxide. Figure 2 (a)-(c) shows the morphology of the produced powders, exhibiting agglomerated nano-

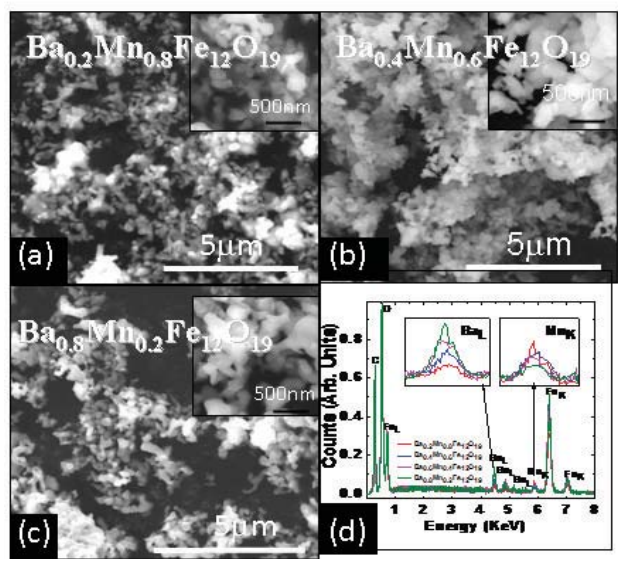

Figure 2. SEM images of $\mathrm{Mn}$ doped Barium ferrite powders: (a) $x=0.8$, (b) $x=0.6$; (c) $x=0.2$; (d) EDS spectra of the sample with insets of $\mathrm{Ba}_{\mathrm{L}}$ and $\mathrm{Mn}_{\mathrm{K}}$ peaks. particles with non-regular shapes, ranging from 50 to $200 \mathrm{~nm}$. All samples appear chemically homogeneous, thus it is not possible to distinguish between $\mathrm{BaFe}_{12} \mathrm{O}_{19}$ and $\alpha-\mathrm{Fe}_{2} \mathrm{O}_{3}$ grains (both can be $\mathrm{Mn}$-doped). In Figure 2 (d) the EDS spectra, obtained from the nanopowders, reveal the presence of $\mathrm{C}$ (due to the carbon glue used to fix the samples), $\mathrm{O}, \mathrm{Fe}, \mathrm{Mn}$ and $\mathrm{Ba}$. The insets of figure 2 (d) clearly show the decrease of the $\mathrm{Mn}_{\mathrm{K}}$ band and the increase of the $\mathrm{Ba}_{\mathrm{L}}$ band, with the increase of Mn content, whereas the Fe bands present constant intensities.

To summarize, composition dependence of magnetic and structural properties of $\mathrm{Ba}_{1-x} \mathrm{Mn}_{x} \mathrm{Fe}_{12} \mathrm{O}_{19}$ powders $(x=0,0.2,0.4,0.6,0.8)$ is reported. With increase of $\mathrm{Mn}$ content, linear decrease of magnetization is observed. Responsible for inferior magnetic properties is $\alpha-\mathrm{Fe}_{2} \mathrm{O}_{3}$ phase formed apart from $\mathrm{BaFe}_{12} \mathrm{O}_{19}$ phase due to $\mathrm{Ba}$ depletion. SEM shows agglomerated nano-particles with non-regular shapes, ranging from 50 to $200 \mathrm{~nm}$.

\section{ACKNOWLEDGEMENTS}

SNK thanks for a visit at IFIMUP (Portugal), ENS de Cachan (France), May-June 2012. AG and MS respectively are financially supported by UGC, Dr. D. S. Kothari Postdoctoral Fellowship scheme [F. 42/2006(BSR)/13-565/ 2011(BSR)] and UGC-DAE CSR, Indore project [CSR-I/CRS51/2011-12].

\section{REFERENCES}

1. X. Obradors, A. Collomb, M. Pernet, D. Samaras and J. C. Joubert, J. Solid State Chem. 56 171-181(1985).

2. N. H. Hur, J. Y. Park, J. Dho, S. J. Kim, and E. K. Lee, IEEE Trans. Magn. 40 2790-2792 (2004).

3. E. F. Kneller and R. Hawig, IEEE Trans. Magn. 27 3560-3588 (1991).

4. S.Castro, M. Gayoso, J. Rivas,J.M. Greneche, J.Mira and C. Rodriguez, J. Magn. Magn. Mater. 152 61-69 (1996). 